\title{
PERENCANAAN STRATEGIS SISTEM INFORMASI DAN TEKNOLOGI INFORMASI PADA DINAS PERINDUSTRIAN DAN TENAGA KERJA KOTA SALATIGA
}

\author{
Yunita Utami' ${ }^{1)}$, Adi Nugroho' ${ }^{2)}$, Agustinus Fritz Wijaya ${ }^{3)}$ \\ 1,2,3 Fakultas Teknologi Informasi, Universitas Kristen Satya Wacana \\ Jl. Notohamidjojo no.1, Salatiga, 50711 \\ Telp : (+62) 298321212 , Fax : (0298) 321433.

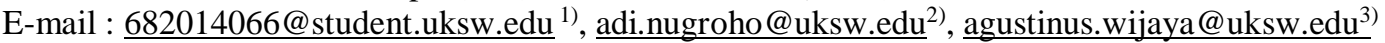

(Naskah masuk: 15 Februari 2018 April 2018, diterima untuk diterbitkan: 5 Juli 2018)

\begin{abstract}
Abstrak
Sistem informasi dan teknologi informasi (SI/TI) merupakan salah satu faktor yang mempengaruhi keberhasilan suatu organisasi. Sebagai contoh, sistem informasi dan teknologi informasi pada salah satu organisasi yang ada yaitu Dinas Perindustrian dan Tenaga Kerja (Dispernaker) Kota Salatiga. SI/TI yang ada pada Dispernaker didalam penggunaanya belum bisa maksimal. Dikarenakan penggunaan SI/TI di dalam Dispernaker belum maksimal menyebabkan data di Dispernaker tidak tersusun dengan baik. Hal ini terjadi data mengalami random. Kemudian sebagian proses bisnis dilakukan secara manual dan saat ini Dispernaker belum memiliki perencanaan strategis SI/TI. Melihat kondisi masalah tersebut maka dibutuhkan suatu perencanaan strategis SI/TI yang dapat mendukung proses bisnis pada organisasi (dalam hal ini Dispernaker) sedangkan perencanaan strategis sendiri merupakan proses bagaimana organisasi mencapai atau merealisasikan tujuannya. Untuk dapat menerapkan perencanaan strategis yang sesuai dengan organisasi tentu melalui sebuah penelitian. Penelitian ini ialah penelitian perencanaan strategis sistem informasi dan teknologi informasi. Penelitian ini sendiri nantinya akan menggunakan metode Ward and Peppard yang dilakukan dengan menganalisis lingkungan bisnis juga lingkungan SI/TI secara internal dan eksternal. Metode tersebut memiliki beberapa analisis, analisis yang digunakan yaitu SWOT, Value Chain dan PEST, Five Force Model, McFarlan Strategic Grid. Dari hasil penelitian ini akan memberikan rekomendasi yang berkaitan dengan visi misi, dengan harapan rekomendasi tersebut dapat digunakan sebagai cara untuk meningkatkan kualitas layanan publik.
\end{abstract}

Kata Kunci: Ward and Peppard; SWOT; Value chain dan PEST; Five Force Model; McFarlan Strategic Grid.

\section{STRATEGIC PLANNING OF INFORMATION SYSTEMS AND INFORMATION TECHNOLOGY AT DEPARTMENT OF INDUSTRY AND LABOR IN SALATIGA CITY}

\begin{abstract}
Information systems and information technology (IS / IT) is one of the factors that influence the success of an organization. For instance, information systems and information technology in an organization called the Department of Industry and Labor (Dispernaker), Salatiga. SI/TI in Dispernaker in its used has not be maximzed yet , because the use of SI/IT in the Dispernaker has not been maximal. This matter causing data in the dispernaker not well structured. This problem Happen because of random Datas. Besides, there are a part of business process that still take manually. Dispenaker Salatiga also doesn't have strategic planning of SI/TI. By the conditions of the problem, we need a strategic plan of IS / IT to support business processes in an organization (in this case Dispernaker) while strategic planning is itself is a process of how organizations achieve theirgoals. To be able to apply strategic planning according to the organization is through a research. The researchis astudy is a strategic planning of information systems and information technology. The research will use Ward and Peppard method by analyzing the business environment and the IS / IT internally and externally. The method has some analysis, the analysis used are SWOT, Value Chain and PEST, Five Force Model, McFarlan Strategic Grid. The results of the study will be recommendations related to the vision and mission. Researcher hopes that these recommendations can be used to improve the quality of public services.
\end{abstract}

Keywords: Ward and Peppard; SWOT; Value chain and PEST; Five Force Model; McFarlan Strategic Grid. 


\section{PENDAhUluan}

Sistem informasi dan teknologi informasi (SI/TI) merupakan salah satu faktor yang mempengaruhi keberhasilan suatu organisasi. Dikarenakan sistem informasi dan teknologi yang akan terus berkembang, maka sebuah organisasi sangat memerlukan perencanaan strategis SI/TI. Robbin dan Coulter (2004) menyatakan bahwa perencanaan mencakup mendefinisikan sasaran organisasi, menetapkan strategi menyeluruh untuk mencapai sasaran itu, dan menyusun serangkaian rencana yang menyeluruh untuk mengintegrasikan dan mengkoordinasikan pekerjaan organisasi. Menurut Tridoyo (2017), sebuah organisasi membutuhkan tata kelola TI (IT Governance) dalam melakukan perencanaan, implementasi, monitoring dan evaluasi TI yang diterapkan.

SI/TI yang ada di Dinas Perindustrian dan Tenaga kerja (Dispernaker) Kota Salatiga belum sepenuhnya digunakan secara maksimal, sehingga menyebabkan data di Dispernaker tidak tersusun dengan baik. Hal ini terjadi dikarenakan data mengalami random. Hasil penerapan SI/TI yang maksimal dapat dilakukan dengan memperbaiki atau memperbarui SI/TI yang ada sehingga memberikan kemudahan dalam mengolah data dan mempermudah proses bisnis organisasi. Dalam menjalankan proses organisasi yang bergerak dalam pelayanan masyarakat, Dispernaker Kota Salatiga mempunyai beberapa permasalahan yaitu, kurangnya sumber daya manusia yang terampil dibidang SI/TI dan sebagian besar sumber daya manusia yang ada belum memahami penggunaan teknologi. Kemudian SI/TI yang tersedia saat ini adalah sistem seleksi kemampuan dasar, sistem informasi pengelolaan keuangan daerah, sistem absen fingerprint dan sistem devinfokerja kemnaker. Sistem devinfokerja kemnaker sendiri belum terintegrasi secara maksimal. Kedepanya Dispernaker ingin memiliki website resmi sebagai sarana informasi bagi masyarakat umum. Diketahui juga sebagian proses bisnis dilakukan secara manual dan Dispernaker belum memiliki perencanaan SI/TI, maka dari itu Dispernaker membutuhkan perencanaan strategis yang akan menentukan SI/TI yang akan digunakan pada masa mendatang.

Melihat permasalahan diatas perlunya adanya perbaikan guna meningkatkan proses bisnis yang ada dan mempermudah pegawai menjalankan tugasnya. Dispernaker sedang merencanakan untuk memeperbaiki SI/TI yang ada namun perbaikan tersebut belum didukung oleh adanya persencanaan strategis SI/TI. Maka peneliti menemukan sebuah gagasan untuk melakukan penelitian dan membuat perencanaan strategis SI/TI. Penelitian ini memberikan rencana implementasi dan juga dokumentasinya dibandingkan solusi sebelumnya yang hanya dilakukan secara lisan.
Penelitian ini dilakukan dengan melihat lingkungan bisnis serta SI/TI secara internal dan eksternal sesuai kondisi saat ini. Penelitian menggunakan metode Ward and Peppard dengan analisis SWOT (Strengths, Weaknesses, Opportunities and Threats), Value chain (rantai nilai), PEST, Five Force Model dan McFarlan. Proses tersebut dapat mengetahui apa saja yang harus ditingkatkan dan menghasilkan rekomendasi sistem yang sesuai dengan kebutuhan Dispernaker kota Salatiga.

\section{METODOLOGI PENELITIAN}

Konsep metodologi penelitian ini menggunakan metode kualitatif yang bertujuan untuk mendeskripsikan dan menganalisis aktivitas sosial yang terjadi. Metode kualitatif didapat melalui permasalahan yang muncul dari data lapangan. Penelitian ini, dilakukan beberapa tahapan yang saling berkaitan antara tahap satu dengan tahap lainnya. Tahapan pertama peneliti mulai mengumpulkan berbagai materi yang dapat mendukung penelitian dan mampu memberikan informasi yang memadai. Materi yang akan dibahas tersebut didapat dari beberapa sumber-sumber pustaka dengan cara membaca buku-buku, melakukan searching di internet dan sumber lainya.

Tahap kedua yang dilakukan proses pengumpulan data dengan melakukan wawancara dan observasi. Dalam hal ini peneliti melakukan observasi secara langsung terhadap objek yang akan di teliti. Melakukan tanya jawab secara lisan kepada Kepala Dinas dan setiap Kepala Bidang Dispernaker Kota Salatiga. Wawancara berkaitan dengan SI/TI yang saat ini digunakan kemudian tujuan dan tugas pokok serta proses bisnis Dispernaker Kota Salatiga.

Kemudian dilakukan analisis terhadap lingkungan bisnis serta lingkungan SI/TI secara eksternal dan internal mengunakan analisis SWOT, analisis Value Chain, analisis PEST, analisis Five Force Model dan analisis McFarlan. Dengan analisis yang telah dilakukan pada Dispernaker Kota Salatiga maka penulis dapat menyusun perencanaan strategis SI/TI yang terdiri dari strategis bisnis, strategis manajemen SI/TI dan strategis TI. Perencanaanperencanaan tersebut selanjuatnya menghasilkan aplikasi portofolio. 


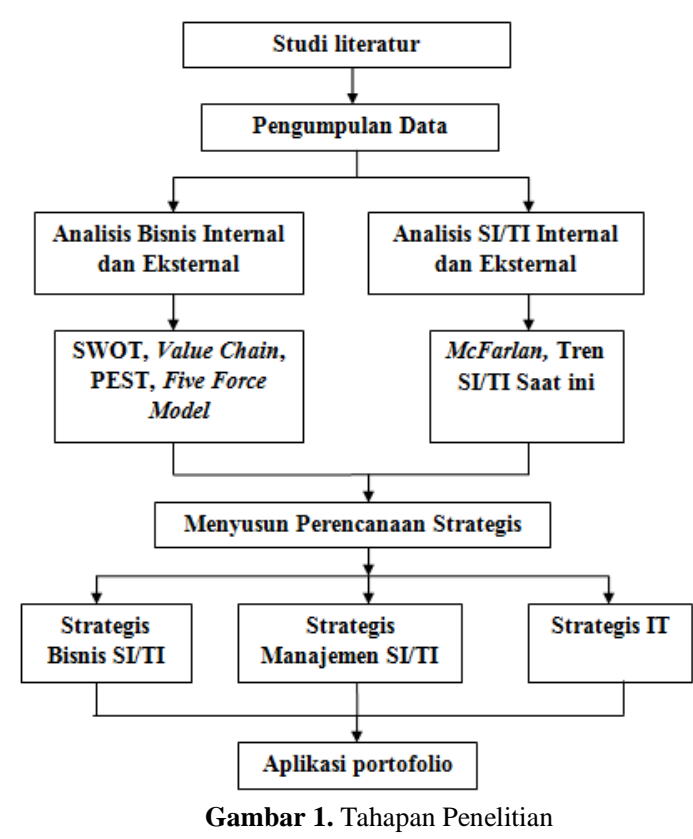

\subsection{Sistem Informasi}

Menurut Mulyanto (2009) sistem informasi adalah kombinasi antarprosedur kerja, informasi, orang dan teknologi informasi yang diorganisasikan untuk mencapai tujuan dalam sebuah organisasi. Kemudian menurut Arifani (2016). Selanjutnya menurut Arifani (2016) sistem informasi merupakan senjata ampuh untuk meningkatkan efisiensi dan efektifitas dalam proses bisnis.

\subsection{Teknologi Informasi}

Menurut Alter (1992) Teknologi informasi mencakup perangkat keras dan perangkat lunak untuk melaksanakan satu atau sejumlah tugas pemprosesan data seperti menangkap, mentransmisikan, menyimpan, mengambil, memanipulasi, atau menampilkan data. Secara garis besar, peranan teknologi informasi adalah menggantikan peran manusia, memperkuat peran manusia dan berperan dalam restrukturisasi terhadap peran manusia.

\subsection{Perencanaan Strategis SI/TI}

Menurut Wredhatama (1999), perencanaan strategis menciptakan strategis bisnis baru bagi sebuah organisasi. Sedangkan perencanaan strategis SI/TI menurut Haris (2002), merupakan dasar untuk melakukan penerapan SI/TI guna memperoleh manfaat bisnis bagi sebuah organisasi. Menurut Wijaya (2011), perencanaan strategis SI/TI juga dapat menjadi salah satu factor bagi sebuah organisasi dalam memperoleh keunggulan kompetitif. Perencanaan strategis SI/TI menurut Ward and Peppard terdiri dari tiga bagian tahapan utama yaitu masukan (input), keluaran (output) dan aplikasi (application). Tahapan masukan terdiri dari lingkungan bisnis internal, lingkungan bisnis eksternal, lingkungan SI/TI internal dan lingkungan SI/TI eksternal. Sedangkan tahapan keluaran terdiri dari strategis manajemen, strategis bisnis sistem informasi dan strategis teknologi informasi. Tahapan aplikasi adalah hasil dari tahapan tersebut kemudian menghasilkan portofolio aplikasi yang dapat digunakan di masa yang akan datang. Menurut Atmaja (2002), Strategi SI menekankan pada penentuan aplikasi sistem informasi yang dibutuhkan organisasi. Esensi dari strategi SI adalah menjawab pertanyaan "apa?". Sedangkan strategi TI lebih menekankan pada pemilihan teknologi, infrastruktur, dan keahlian khusus yang terkait atau menjawab pertanyaan "bagaimana?". Di dalam tahapan perencanaan strategis SI/TI tersebut di dalamnya terdapat analisis yang dikembangkan oleh Ward and Peppard. Berikut gambar model perencanaan strategis SI/TI menurut Ward and Peppard:

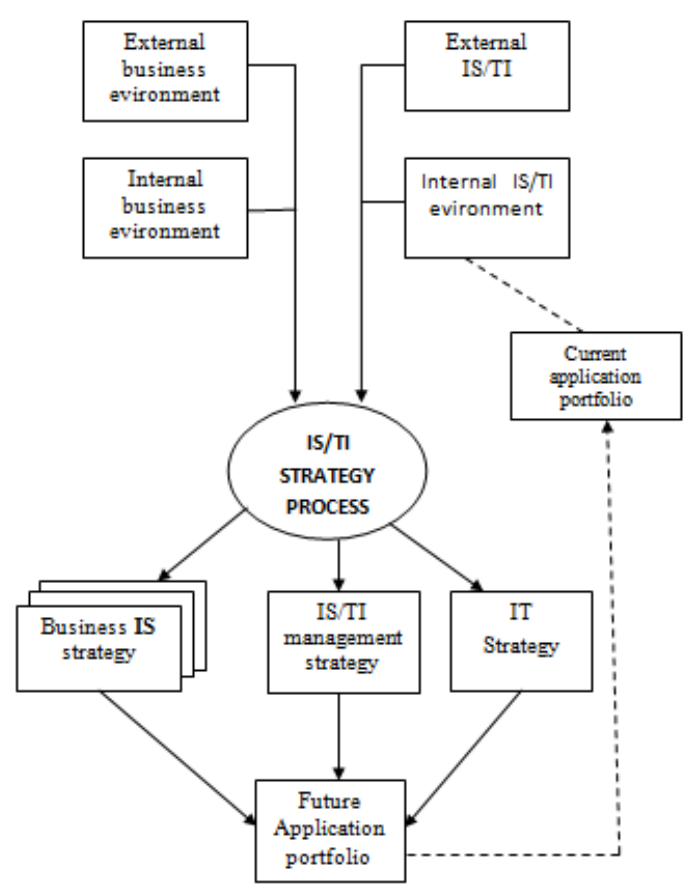

Gambar 2. Perencanaan Strategis SI/TI (Ward and Peppard, 2002)

Analisis yang dikembangkan oleh Ward and Peppard terdiri dari analisis SWOT, analisis Value Chain, analisis PEST, analisis Five Force Model dan analisis McFarlan. Berikut penjelasan analisis tersebut:

\subsubsection{Analisis SWOT}

Menurut Jogiyanto (2006), analisis SWOT (Strengths, Weaknesses, Opportunities and Threats) yang dilakukan dengan melihat lingkungan bisnis internal dan eksternal untuk mengindetifikasi kekuatan - kekuatan, kelemahan - kelemahan, kesempatan - kesempatan dan ancaman-ancaman yang ada pada organisasi. Kemudian menurut Rangkuti (2014) Proses pengambilan keputusan strategis selalu berkaitan dengan pengembangan misi, tujuan, strategi, dan kebijakan perusahaan. Hasil indetifikasi dapat digunakan sebagai cara untuk menggunakan sumber daya organisasi dengan mempertimbangkan situasi internal dan eksternal 
organisasi kemudian dapat membangun basis sumber daya organisasi. Berikut Tabel matrik analisis SWOT:

\begin{tabular}{cc} 
Tabel 1. Matrik SWOT (Ward and Peppard, 2002) \\
\hline Strengths & Weaknesses \\
\hline $\begin{array}{c}\text { Faktor-faktor yang } \\
\text { menimbulkan } \\
\text { kekuatan dalam } \\
\text { organisasi. }\end{array}$ & $\begin{array}{c}\text { Faktor-faktor yang } \\
\text { menimbulkan } \\
\text { kelemahan dalam } \\
\text { organisasi. }\end{array}$ \\
\hline $\begin{array}{c}\text { Faktor-faktor yang } \\
\text { menimbulkan } \\
\text { peluang bagi } \\
\text { organisasi }\end{array}$ & $\begin{array}{c}\text { Faktor-faktor yang } \\
\text { mendatangkan } \\
\text { ancaman bagi } \\
\text { organisasi }\end{array}$ \\
\hline Opportunities & Threats
\end{tabular}

\subsubsection{Analisis Value Chain}

Analisis Value Chain yang dilakukan dengan melihat lingkungan bisnis internal yang berfokus pada aktivitas utama dan aktivitas pendukung. Aktivitas dilakukan dengan melihat tugas dan fungsi setiap bidang organisasi. Menurut Irmayani (2016) prinsip dari value chain adalah bagaimana memetakan seluruh proses kerja atau aktivitas dalam institusi tersebut ke dalam dua bagian yaitu, aktivitas utama dan aktivitas pendukung. Tujuan dari analisis ini untuk menciptakan kemampuan kompetitif pada organisasi.

\begin{tabular}{|c|c|c|c|c|c|}
\hline \multicolumn{2}{|c|}{$\begin{array}{l}\text { Suppon activities } \\
\text { Infrastructure }\end{array}$} & \multicolumn{3}{|c|}{ - Legal, accounting, firancial managenent } & \\
\hline \multicolumn{2}{|l|}{$\begin{array}{l}\text { Humanresource } \\
\text { management }\end{array}$} & \multicolumn{3}{|c|}{$\begin{array}{l}\text { - Personnel, pay, recruitment, training, } \\
\text { monpower planning, etc. }\end{array}$} & \\
\hline \multicolumn{2}{|c|}{$\begin{array}{l}\text { Product and technology } \\
\text { development }\end{array}$} & \multicolumn{3}{|c|}{$\begin{array}{l}\text { - Product and process design, production engineering, } \\
\text { market testing, RBD, etc. }\end{array}$} & \\
\hline \multicolumn{2}{|l|}{ Procurement } & \multicolumn{3}{|c|}{$\begin{array}{l}\text { - Supplier management, funding, } \\
\text { subcontracting, specification }\end{array}$} & \\
\hline $\begin{array}{l}\text { INBOUND } \\
\text { LOCISTICS } \\
\text { For exanple: } \\
\text { quality control; } \\
\text { receiving; } \\
\text { raw malerials } \\
\text { control; etc. }\end{array}$ & $\begin{array}{l}\text { OPERATIONS } \\
\text { For example: } \\
\text { manufacturing; } \\
\text { packaginy; } \\
\text { producticn } \\
\text { control; } \\
\text { quality control; } \\
\text { maintenance; } \\
\text { etc. }\end{array}$ & $\begin{array}{l}\text { OUTBOUND } \\
\text { LOCISTICS } \\
\text { For example: } \\
\text { finishing grods } \\
\text { order handling; } \\
\text { dispatch; } \\
\text { delivery; } \\
\text { invoicing; ttc. }\end{array}$ & $\begin{array}{l}\text { SALES \& } \\
\text { MARKETINC } \\
\text { For example: } \\
\text { customer } \\
\text { management; } \\
\text { order taking } \\
\text { promotion; } \\
\text { sales analysis; } \\
\text { morkot } \\
\text { research; et:. }\end{array}$ & $\begin{array}{l}\text { SERVICING } \\
\text { For example: } \\
\text { warranty; } \\
\text { maintenance; } \\
\text { education and } \\
\text { training; } \\
\text { upgrades; etc. }\end{array}$ & \\
\hline
\end{tabular}

Gambar 3. Value Chain (Ward and Peppard, 2002)

\subsubsection{Analisis PEST}

Analisis PEST yang dilakukan dengan melihat lingkungan bisnis eksternal yang melihat dari empat faktor pada bidang politik, bidang ekonomi, bidang sosial dan bidang teknologi. Analisis ini untuk memahami pertumbuhan dan arahan potensi pada organisasi. Dalam kerangka kerja Ward and Peppard PEST memiliki faktor-faktor yang lebih luas, yang melebihi empat faktor di gambarkan sebagai berikut:

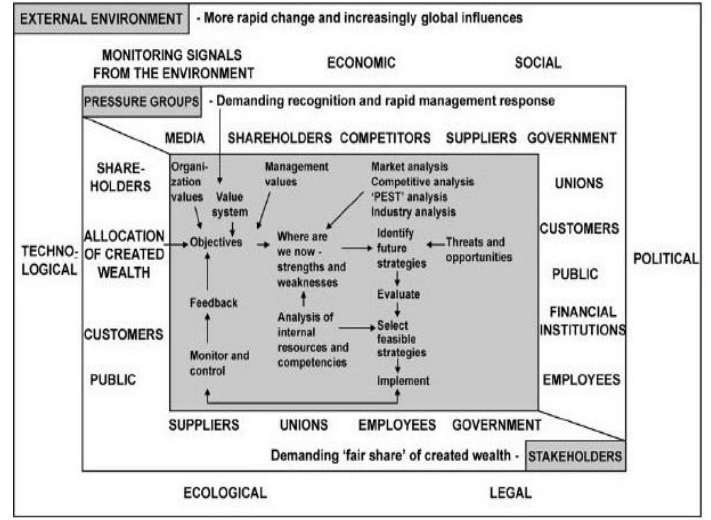

Gambar 4. Faktor yang Mempengaruhi Kerangka Kerja Strategis (Ward and Peppard, 2002)

\subsubsection{Analisis Five Force Model}

Analisis Five Force Model yang dilakukan dengan melihat lingkungan bisnis eksternal dan berdasarkan lima kekuatan kompetitif. Tujuan analisis ini untuk mengetahui posisi organisasi saat ini. Lima kekuatan tersebut digambarkan sebagai berikut:

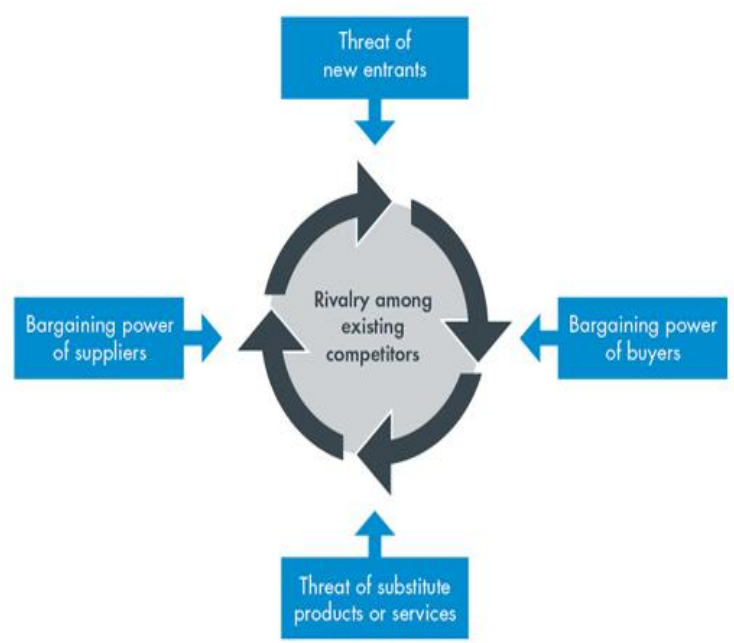

Gambar 5. Five Force Model (Ward and Peppard, 2002)

\subsubsection{Analisis McFarlan}

Analisis McFarlan yang dilakukan dengan melihat lingkungan SI/TI secara internal. Pemetaan yang dilakukan dengan kondisi sistem informasi yang sangat berpengaruh di masa yang akan datang, sistem informasi yang diangap sangat penting dalam kelangsungan proses bisnis, sistem informasi yang mempermudah operasional, dan sistem informasi yang mendukung aktivitas bisnis organisasi (Strategic, high Potential, key operational dan support). Hasil dari pemetaan dapat memberikan rekomendasi sistem informasi. Pemetaan dapat digambarkan sebagai berikut: menggunakan metode Ward and Peppard.

Tabel 2. McFarlan (Ward and Peppard, 2002)

\begin{tabular}{cc}
\hline STRATEGIC & HIGH POTENTIAL \\
\hline Applications that are & Applications that may be \\
critical to sustaining & important in achieving \\
future business strategy & future success
\end{tabular}




\begin{tabular}{cc}
\hline $\begin{array}{c}\text { Applications on which } \\
\text { the organization } \\
\text { currently depends for } \\
\text { success }\end{array}$ & $\begin{array}{c}\text { Applications that are } \\
\text { valuable but not critical } \\
\text { to success }\end{array}$ \\
\hline KEYOPERATIONAL & SUPPORT \\
\hline
\end{tabular}

\section{HASIL DAN ANALISIS}

\subsection{Analisis Lingkungan Bisnis \\ Internal/Eksternal}

Tahap awal penelitian ini dengan menggunakan Analisis SWOT (Strength, Weaknesses, Opportunites and Threats) dilakukan untuk mengetahui kekuatan, kelemahan, peluang dan ancaman dengan melihat lingkungan bisnis secara internal dan eksternal pada Dispernaker Kota Salatiga. Berikut hasil dari analisis:

\begin{tabular}{|c|c|}
\hline Strength & Weaknesses \\
\hline $\begin{array}{ll}\text { - } & \text { Informasi } \\
\text { lowongan kerja } \\
\text { yang dibuat secara } \\
\text { akurat dan } \\
\text { terpercaya } \\
\text { Tersedia Sistem } \\
\text { informasi pasar } \\
\text { kerja }\end{array}$ & $\begin{array}{ll}\text { - } & \text { Kurangnya } \\
\text { sumber daya } \\
\text { manusia pada } \\
\text { setiap bidang } \\
\text { - } \quad \text { Teknologi yang } \\
\text { ada masih } \\
\text { terbatas } \\
\text { - } \quad \text { Informasi tidak } \\
\text { sampai ke } \\
\text { masyarakat }\end{array}$ \\
\hline Opportunities & Threats \\
\hline $\begin{array}{ll}\text { - } & \text { Kegiatan yang } \\
\text { diharapkan } \\
\text { masyarakat } \\
\text { Kesempatan } \\
\text { perusahaan, } \\
\text { pemborong } \\
\text { pekerjaan dan } \\
\text { penyedia jasa } \\
\text { untuk mendapatkan } \\
\text { informasi tenaga } \\
\text { kerja } \\
\text { Kesempatan bagi } \\
\text { pencari kerja untuk } \\
\text { mendapatkan } \\
\text { pekerjaan }\end{array}$ & $\begin{array}{ll}\text { - } & \text { Kurangnya } \\
\text { kesadaran } \\
\text { Perusahaan } \\
\text { untuk wajib } \\
\text { lapor } \\
\text { - } \quad \text { Perusahaan, } \\
\text { pemborong } \\
\text { pekerjaan dan } \\
\text { pemyedia jasa } \\
\text { tidak menaati } \\
\text { peraturan } \\
\text { pemerintah } \\
\text { Minat } \\
\text { masyarakat yang } \\
\text { masih kurang }\end{array}$ \\
\hline
\end{tabular}

Dari hasil analisis SWOT tersebut kemudian dirumuskan untuk dapat digunakan sebagai strategis perencanaan SI/TI pada Dispernaker Kota Salatiga, sebagai berikut.

\section{Strength and Opportunities (SO)}

Memanfaatkan informasi lowongan kerja yang akurat dan terpercaya sehingga memberi kesempatan pencari kerja untuk mendapatkan pekerjaan sesuai dengan yang diinginkan.

\section{Strength and Threats (ST)}

Tersedia sistem informasi pasar kerja dapat di manfaatkan sebagai daya tarik masyarakat untuk mendapatkan informasi lowongan kerja. Kemudian meningkatkan pemantauan pada perusahaan yang ada di Kota Salatiga untuk dapat memberikan kesadaran wajib lapor.

\section{Weaknesses and Opportunities (WO)}

Menambah jumlah Sumber Daya Manusia yang terampil pada setiap bidang agar kegiatan yang di inginkan masyarakat dapat terlaksana.

\section{Weaknesses and Threats (WT)}

Meningkatkan informasi seperti mengenai hak sebagai pekerja sehingga masyarakat tidak mudah ditipu oleh perusahaan, pemborong pekerjaan dan penyedia jasa yang tidak menaati peraturan pemerintah.

Analisis Value Chain dilakukan untuk mengetahui proses kerja Dispernaker Kota Salatiga. Analisis dilakukan dengan melihat lingkungan bisnis secara internal pada Dispernaker Kota Salatiga. Analisis Value Chain ini mengidentifikasi aktivitasaktivitas yang berfokus pada aktivitas utama dan aktivitas pendukung. Berikut hasil dari analisis Value Chain yang didapat:

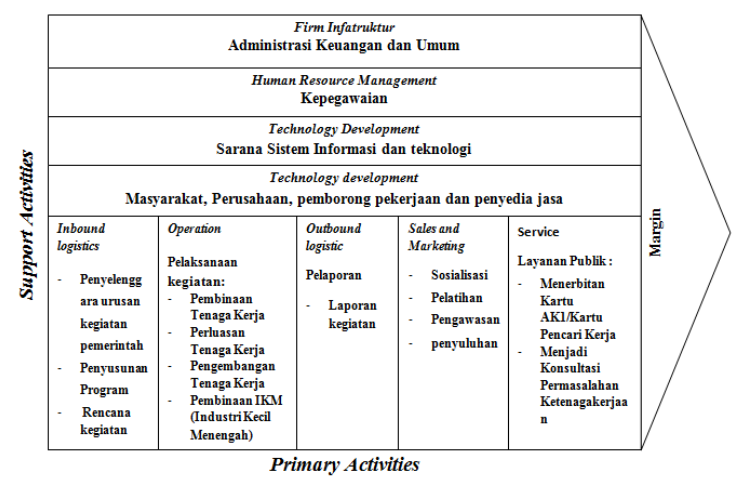

Gambar 6. Value Chain Analysis Dispernaker Kota Salatiga

Aktivitas utama yang harus dilakukan untuk mencapai tujuan bisnis pada Dispernaker Kota Salatiga sebagi berikut:

1. Penyelenggara urusan kegiatan pemerintah

2. Penyusunan Program

3. Rencana kegiatan

4. Pelaksanaan kegiatan:

- Pembinaan Tenaga Kerja

- Perluasan Tenaga Kerja

- Pengembangan Tenaga Kerja

- Pembinaan IKM (Industri Kecil Menengah)

5. Laporan kegiatan

6. Sosialisasi

7. Pelatihan

8. Pengawasan

9. Penyuluhan

10. Layanan Publik:

- Menerbitan Kartu AK1/Kartu Pencari Kerja

- Menjadi Konsultasi Permasalahan Ketenagakerjaan

Kemudian Aktivitas pendukung harus dilakukan untuk mencapai tujuan bisnis Dispernaker Kota Salatiga sebagai berikut:

1. Administrasi Keuangan dan Umum

2. Kepegawaian

3. Sarana Sistem Informasi dan teknologi 
4. Masyarakat, Perusahaan, pemborong pekerjaan dan penyedia jasa

Tahap selanjutnya dilakukan analisis PEST (politic, economy, social, technology) dengan melihat lingkungan bisnis eksternal. Analisis ini berfokus pada politik, ekonomi, sosial dan teknologi.

\section{Politik}

Berdasarkan UU Nomor 13 Tahun 2003 tentang Ketenagakerjaan dan Nomor 2 Tahun 2004 tentang Penyelesaian Perselisihan Hubungan Industrial. Sesuai dengan hal tersebut Dispernaker Kota Salatiga memiliki peran penting untuk memberikan pelayanan dibidang perindustrian dan bidang ketenagakerjaan.

\section{Ekonomi}

Data BPS, pengangguran tahun 2016 Kota Salatiga mencapai 5.577 orang sedangkan tingkat Nasional tahun 2016 mencapai 7,56 juta orang/Agustus. Kemudian data pencari kerja tahun 2016 hanya 4.137 orang dan angka kerja tahun 2016 kurang lebih 92.822 orang. Melihat permasalahan tersebut menjadi masalah prioritas yang dapat berdampak pada ekonomi yang ada di Kota Salatiga sehingga angka kemiskinan semakin tinggi. Dengan kondisi tersebut Dispernaker Kota Salatiga melakukan langkah-langkah untuk mengatasi kondisi pengangguran dan pencari kerja dengan melakukan program dan pelatihan.

\section{Sosial}

Melihat kondisi ekonomi tersebut adanya latar belakang permasalahan bagi pencari kerja yang pertama kualifikasi pencari kerja tidak sesuai dengan persyaratan kerja atau jabatan. Kedua tidak mengetahui informasi tentang dunia kerja maupun informasi kerja. Ketiga pencari kerja tidak dapat memahami potensi dirinya, sehingga tidak dapat mengisi kesempatan kerja sesuai dengan persyaratan pekerjaan atau jabatan yang ada. Hal tersebut menjadikan Dispernaker Kota Salatiga untuk memberikan arahan kepada pencari kerja.

\section{Teknologi}

Teknologi akan terus berkembang, maka perlu adanya teknologi yang memadai untuk mempermudah kegiatan-kegiatan proses bisnis pada organisasi. Dispernaker Kota Salatiga membutuhkan teknologi yang dapat meningkatkan pelayanan masyarakat dan mempermudah proses kegiatan yang akan dilakukan.

Kemudian dilakukan analisis Five Force Model untuk mengetahui posisi Dispernaker Kota Salatiga saat ini. Analisis yang dilakukan dengan memetakan kegiatan diluar organisasi ke dalam lima kekuatan kompetitif. Berikut hasil dari analisis Five Force Model:

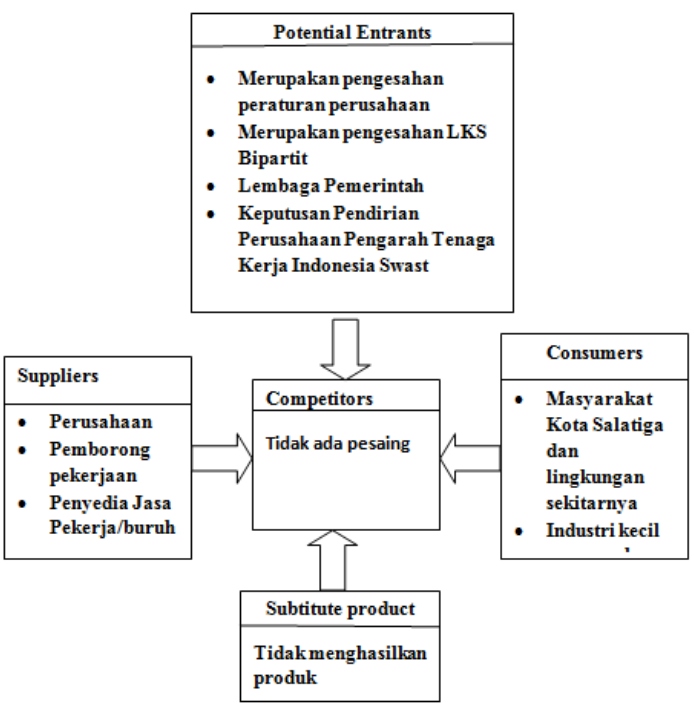

Gambar 7. Five Force Model Dispernaker Kota Salatiga

3.2 Analisis Lingkungan SI/TI Internal/Eksternal

Selanjutnya Analisis Matrik McFarlan yang merupakan analisis dengan melihat kondisi SI/TI secara internal. Berikut daftar SI/TI yang digunakan pada Dispernaker Kota Salatiga berdasarkan kondisi saat ini:

Tabel 4. Daftar SI/TI Dispernaker Kota Salatiga.

\begin{tabular}{|c|c|c|c|}
\hline No & $\begin{array}{l}\text { Nama Sistem } \\
\text { Informasi }\end{array}$ & Pengguna & $\begin{array}{c}\text { Nama } \\
\text { Aplikasi }\end{array}$ \\
\hline 1. & $\begin{array}{c}\text { Sistem } \\
\text { Devinfokerja } \\
\text { Kemnaker }\end{array}$ & $\begin{array}{c}\text { Bidang } \\
\text { Ketenaga } \\
\text { Kerjaan }\end{array}$ & Web Based \\
\hline 2. & $\begin{array}{l}\text { Sistem Seleksi } \\
\text { Kemampuan } \\
\text { Dasar (SKD) } \\
\text { Salatiga }\end{array}$ & $\begin{array}{c}\text { Kasubag } \\
\text { Umum \& } \\
\text { Kepegawaian }\end{array}$ & Web Based \\
\hline 3 & $\begin{array}{l}\text { Sistem } \\
\text { Informasi } \\
\text { Pengelolaan } \\
\text { Keuangan } \\
\text { Daerah } \\
\text { (SIPKD) } \\
\text { Salatiga }\end{array}$ & $\begin{array}{c}\text { Kasubag } \\
\text { Perencanaan \& } \\
\text { Keuangan }\end{array}$ & Web Based \\
\hline 4 & $\begin{array}{l}\text { Sistem Absen } \\
\text { Fingerprint }\end{array}$ & $\begin{array}{c}\text { Pegawai } \\
\text { Dispernaker }\end{array}$ & Biometrik \\
\hline 5 & $\begin{array}{l}\text { Ms. Office } \\
\text { (Excel dan } \\
\text { Word) }\end{array}$ & $\begin{array}{c}\text { Pegawai } \\
\text { Dispernaker }\end{array}$ & Desktop \\
\hline
\end{tabular}

Setelah mengetahui SI/TI yang digunakan pada Dispernaker Kota Salatiga selanjutnya dilakukan pemetaan matrik McFarlan. Berikut hasil pemetaan:

\begin{tabular}{|c|c|}
\hline STRATEGIC & HIGH POTENTIAL \\
\hline $\begin{array}{ll}\text { - } & \text { Sistem } \\
\text { Devinfokerja } \\
\text { Kemnaker }\end{array}$ & $\begin{array}{ll}\text { - } & \text { Sistem Seleksi } \\
\text { Kemampuan } \\
\text { Dasar (SKD) } \\
\text { Salatiga } \\
\end{array}$ \\
\hline $\begin{array}{l}\text { - } \\
\text { Sistem Informasi } \\
\text { Pengelolaan } \\
\text { Keuangan Daerah } \\
\text { (SIPKD) Salatiga }\end{array}$ & $\begin{array}{l}\text { - Ms. Office (Excel } \\
\text { dan Word) } \\
\text { - } \quad \text { Absen } \\
\text { Fingerprint }\end{array}$ \\
\hline $\begin{array}{c}\text { KEY } \\
\text { OPERATIONAL }\end{array}$ & SUPPORT \\
\hline
\end{tabular}


Kemudian dilihat dari SI/TI eksternal dengan melihat tren SI/TI saat ini. Banyak organisasi atau perusahaan cenderung menggunakan SI/TI seperti jaringan, perangkat lunak, perangkat keras dan pengamanan SI/TI lainya. Terdapat banyak manfaat dengan menggunakan tren SI/TI pada organisasi seperti meningkatkan layanan publik, mempermudah proses kerja kemudian memudahkan orang berkomunikasi dan memperoleh informasi.

\subsection{Strategis Bisnis SI/TI}

Berdasarkan analisis-analisis yang telah dilakukan maka menghasilkan rekomendasi yang dapat digunakan Dispernaker Kota Salatiga. Rekomendasi tersebut dapat digunakan untuk meningkatkan proses bisnis SI/TI, sebagai berikut:

1. Membuat sistem informasi pada bidang perindustrian dan bidang ketenagakerjaan untuk menyimpan data-data yang ada sehingga data tidak mengalami kerusakan ataupun kehilangan.

2. Membuat website resmi Dispernaker Kota Salatiga untuk memberikan informasi tentang program kerja, baik industri dan tenaga kerja yang akan dilakukan.

3. Mengoptimalkan Aplikasi Devinfokerja Kemnaker berbasis teleconference atau videoconference dan Sistem Seleksi Kemampuan Dasar (SKD) Salatiga lebih dioptimalkan dalam penggunaanya.

4. Memberikan pelatihan kepada sumber daya manusia yang ada mengenai SI/TI.

5. Menambah sumber daya manusia yang terampil terkait SI/TI.

6. Perlu adanya peningkatan keamanan sistem informasi seperti backup data dan maintanace secara rutin

\subsection{Strategis Manajemen SI/TI}

Analisis yang telah dilakukan didapati Dispernaker Kota Salatiga saat ini belum memiliki penanganan khusus pada SI/TI. Melihat kondisi tersebut Dispernaker Kota Salatiga perlu memiliki divisi SI/TI untuk pembuatan dan pengembangan SI/TI. Untuk pembuatan dan pengembangan SI/TI perlu adanya peningkatan anggaran SI/TI pada Dispernaker Kota Salatiga.

\subsection{Strategis TI}

Mengetahui SI/TI yang saat ini digunakan perlu adanya pengembangan aplikasi untuk meningkatkan kinerja pada Dispernaker Kota Salatiga. Salah satunya perlu adanya maintanance dan perlu ditingkatkan sumber daya seperti hardware sesuai dengan kebutuhan setiap bidang. Selanjutnya penggunaan aplikasi Dispernaker Kota Salatiga yang ada digunakan lebih secara maksimal dan menambah aplikasi pada setiap bidang untuk membantu aktivitas-aktivitas yang dilakukan.

\subsection{Aplikasi Portofolio}

Dari hasil analisis yang telah dilakukan maka menghasilkan usulan portofolio sebagai berikut:

Tabel 6. Usulan SI/TI untuk Dispernaker Kota Salatiga No Pengguna SI/TI saat ini SI/TI Usulan

\begin{tabular}{|c|c|c|c|}
\hline 1. & $\begin{array}{l}\text { Kasubag } \\
\text { Umum \& } \\
\text { Kepegawaian }\end{array}$ & $\begin{array}{l}\text { - Sistem } \\
\text { Seleksi } \\
\text { Kemampuan } \\
\text { Dasar (SKD) } \\
\text { Salatiga } \\
\text { - Finger Print }\end{array}$ & $\begin{array}{l}\text { - Website } \\
\text { Dispernaker } \\
\text { Kota salatiga } \\
\text { agar } \\
\text { masyarakat } \\
\text { mengetahui } \\
\text { informasi } \\
\text { tentang } \\
\text { perindustrian } \\
\text { dan tenaga } \\
\text { kerja } \\
\text { - Sistem } \\
\text { penyimpanan } \\
\text { surat masuk } \\
\text { dan surat keluar }\end{array}$ \\
\hline 2. & $\begin{array}{l}\text { Bidang } \\
\text { Ketenaga } \\
\text { Kerjaan }\end{array}$ & $\begin{array}{l}\text { - Sistem } \\
\text { Devinfokerja } \\
\text { Kemnaker } \\
\text { - Ms. Office } \\
\text { (Excel dan } \\
\text { Word) }\end{array}$ & $\begin{array}{l}\text { - } \text { Sistem } \\
\text { Penyimpanan } \\
\text { data PHK dan } \\
\text { Pelatihan } \\
\text { - SMS Gateway } \\
\text { - Sistem } \\
\text { penyimpanan } \\
\text { data } \\
\text { perusahaan, } \\
\text { pemborong dan } \\
\text { penyedia jasa } \\
\text { pekerja/buruh }\end{array}$ \\
\hline 3. & $\begin{array}{l}\text { Bidang } \\
\text { Perindustrian }\end{array}$ & $\begin{array}{l}\text { - Ms. Office } \\
\text { (Excel dan } \\
\text { Word })\end{array}$ & $\begin{array}{l}\text { - } \text { Sistem } \\
\text { Penyimpanan } \\
\text { data IKM } \\
\text { - SMS Gateway }\end{array}$ \\
\hline
\end{tabular}

Hasil Portofolio kemudian dilakukan rencana implementasi yang dapat dilakukan Dispernaker Kota Salatiga dalam kurun waktu 4 tahun ke depan.

\begin{tabular}{|c|c|c|c|c|}
\hline Solusi SI/TI & 2018 & 2019 & 2020 & 2021 \\
\hline $\begin{array}{l}\text { Mengoptimalka } \\
\mathrm{n} \text { aplikasi } \\
\text { Devinfokerja }\end{array}$ & $\begin{array}{l}\text { Strat } \\
\text { egic }\end{array}$ & & & \\
\hline $\begin{array}{l}\text { Website } \\
\text { Dispernaker } \\
\text { Kota salatiga }\end{array}$ & & $\begin{array}{l}\text { Suppor } \\
t\end{array}$ & & \\
\hline SMS Gateway & & & & \\
\hline $\begin{array}{l}\text { Sistem } \\
\text { Penyimpanan } \\
\text { data PHK dan } \\
\text { Pelatihan } \\
\end{array}$ & & & $\begin{array}{l}\text { key } \\
\text { operati } \\
\text { onal }\end{array}$ & \\
\hline $\begin{array}{l}\text { Sistem } \\
\text { penyimpanan } \\
\text { data } \\
\text { perusahaan, } \\
\text { pemborong dan } \\
\text { penyedia jasa } \\
\text { pekerja/buruh }\end{array}$ & & & & \\
\hline $\begin{array}{l}\text { Sistem } \\
\text { Penyimpanan } \\
\text { data IKM }\end{array}$ & & & & \\
\hline $\begin{array}{l}\text { Sistem } \\
\text { penyimpanan } \\
\text { surat masuk dan } \\
\text { surat keluar }\end{array}$ & & & & $\begin{array}{l}\text { high } \\
\text { Potenti } \\
\text { al }\end{array}$ \\
\hline
\end{tabular}

\section{KESIMPULAN DAN SARAN}

Berdasarkan penelitian yang telah dilakukan dapat menggambil kesimpulan yaitu, Dispernaker Kota Salatiga hingga saat ini belum memiliki perencanaan SI/TI. Kondisi SI/TI yang ada belum dapat menyimpan data dengan baik dan peru adanya SI/TI yang baru untuk mempermudah poreses kerja 
dalam organisasi. Dengan adanya penelitian perencanaan strategis SI/TI pada Dispernaker Kota Salatiga dengan metode Ward and Peppard menggunakan analisis SWOT, Value chain, PEST, Five Force Model dan McFarlan dapat mengetahui apa yang harus diperbaiki dan yang harus di kembangkan. Perencanaan strategis SI/TI yang telah dilakuakan menghasilkan rekomendasi portofolio aplikasi yang sesuai dengan kebutuhan dan kondisi Dispernaker Kota Salatiga. Kemudian portofolio ini dapat diimpementasikan 4 tahun ke depan.

Beberapa saran yang dapat digunakan untuk penelitian selanjutnya sebagai berikut:

1. Perencanaan strategis sistem informasi dan teknologi informasi ini dapat di implementasikan agar proses kinerja Dispernaker Kota Salatiga lebih optimal.

2. Perencanaan strategis sistem informasi dan teknologi informasi ini dapat dilakukan kembali dalam jangka waktu tertentu.

3. Perencanaan strategis sistem informasi dan teknologi informasi belum meliputi seluruh aspek, karena hanya melihat kinerja organisasi yang lebih berfokus pada bidang industri dan tenaga kerja. Untuk penelitian berikutnya dapat berfokus pada keseluruhannya sehingga dapat memberikan saran yang lebih relavan.

\section{DAFTAR PUSTAKA}

ALTER, S., 1992. Information systems: A Management Perspective. The Benjamin/Cummings Publishing Company, Inc.

ARIFANI, N.I. dan DARMAWAN, A., 2016. Perencanaan Strategis Sistem Informasi dan Teknologi Informasi SI/TI Pendidik dan Tenaga Kependidikan. Jurnal Teknologi Informasi Magister 2 (1), 41-51.

ATMAJA, 2002. Penyusunan Metodologi Perencanaan Strategis Sistem Informasi Berbasis Value Bisnis (Be Vissta Planning) dalam Rangka Meningkatkan Peran Strategis Sistem Informasi pada Suatu Organisasi, Jurnal Fakultas Ilmu Komputer, Universitas Indonesia, Jakarta, Indonesia.

HARIS, W., 2002. Penyusunan Metodologi Perencanaan Strategis Sistem Informasi Berbasis Value Bisnis (Be Vissta Planning) dalam rangka Meningkatkan Peran Strategis Sistem Informasi pada Suatu Organisasi. Jakarta: Universitas Indonesia.

IRMAYANI, W., 2016. Perancangan Strategis Sistem dan Teknologi Informasi pada Dinas Cipta Karya, Tata Ruang, dan Kebersihan Kabupaten Kubu Raya, Kalimantan Barat. Jurnal Informatika dan Sistem Informasi 2(1), 16-25.

JOGIYANTO., 2006. Sistem Informasi Strategi untuk Keunggulan Kompetitif. Yogyakarta: ANDI.
MULYANTO, A., 2009. Pengertian Sistem Informasi dalam Sistem Informasi Konsep dan Aplikasi. Yogyakarta: ANDI.

RANGKUTI, F., 2014. Analisis SWOT: Teknik Membedah Kasus Bisnis Cara Perhitungan Bobot, Rating dan OCAI. Jakarta: PT. Gramedia.

ROBBINS, S.P. dan COULTER, M., 2004. Manajemen, Alih Bahasa T. Hermaya dan Harry Slamet, Jilid I, Edisi ketujuh. Jakarta: PT. Indeks.

TRIDOYO, dan WIJAYA, A.F., 2017. Analysis of Information Technology Governance e-KTP using COBIT 5 Framework. Salatiga: ICITECH.

WARD, J., \& PEPPARD, J., 2002. Strategic Planning for Information System. England: John Wiley \& Sons.

WIJAYA, A.F., 2011. Perencanaan Strategis Sistem Informasi dalam rangka meningkatkan Keunggulan Kompetitif Perguruan Tinggi Menggunakan Metode Be Vissta Planning (Studi Kasus : UKSW Salatiga). Salatiga: Jurnal Magister Sistem Informasi, Universitas Kristen Satya Wacana.

WEDHASMARA. A., 1999. Langkah - Langkah Perencanaan Strategis Sistem Informasi dengan Menggunakan Metode Ward and Peppard. Jurnal Sistem Informasi, Vol. 1, No. 1, pp. 14-22 